\title{
Assessing the Argument for Specialized Courts: Evidence from Family Courts in Spain
}

Nuno Garoupa

ngaroup@gmu.edu

Natalia Jorgensen

Pablo Vazquez

Follow this and additional works at: https://scholarship.law.tamu.edu/facscholar

Part of the Law Commons

\section{Recommended Citation}

Nuno Garoupa, Natalia Jorgensen \& Pablo Vazquez, Assessing the Argument for Specialized Courts: Evidence from Family Courts in Spain, 24 Int'I J.L. Pol'y \& Fam. 54 (2010).

Available at: https://scholarship.law.tamu.edu/facscholar/444

This Article is brought to you for free and open access by Texas A\&M Law Scholarship. It has been accepted for inclusion in Faculty Scholarship by an authorized administrator of Texas A\&M Law Scholarship. For more information, please contact aretteen@law.tamu.edu. 


\author{
ASSESSING THE ARGUMENT FOR \\ SPECIALIZED COURTS: EVIDENGE FROM \\ FAMILY COURTS IN SPAIN \\ NUNO GAROUPA, * NATALIA JORGENSEN, ${ }^{\dagger}$ AND \\ PABLO VAZQUEZ ${ }^{\ddagger}$

\begin{abstract}
*Professor of Law, University of Illinois College of Law. E-mail: ngaroupa@illinois.edu
${ }^{\dagger}$ Doctoral Candidate and Researcher, FEDEA, Madrid. E-mail: njorgensen@fedea.es ¥Professor of Economics and Director, Universidad Complutense de Madrid, FEDEA, Madrid. E-mail: pvazquez@fedea.es
\end{abstract}

\begin{abstract}
Specialized courts have become a key component of the legal reform packages implemented in civil law countries, particularly, in the area of family law. One argument for this policy is that they are able to reach a decision faster than the regular courts, which are normally congested. We use data from a survey of Spanish family courts in the region of Madrid to test this claim. After controlling for other relevant variables, the econometric results did not provide strong support for specialized courts.
\end{abstract}

\title{
INTRODUCTION
}

Specialized courts have become an essential component of legal reform packages in civil law countries. ${ }^{1}$ While they are less popular in common law countries, these courts have nevertheless been emerging. ${ }^{2}$ The widespread enthusiasm for specialized courts enjoyed by legal policymakers is not always shared in legal academia. ${ }^{3}$ Moreover, many of the advantages of specialized courts that are emphasized by legal policymakers have not been empirically validated. In particular, it is not clear if specialized courts assure higher quality decisions in a shorter time frame (ie, more efficiently than in the congested court system).

The authors acknowledge the financial support of Fundación Rafael del Pino for this research, the help provided by the Spanish Judicial Council (Consejo General del Poder Judicial) in accessing the data, and research assistance of Paloma Leal and María Dólores Delgado Inglada for gathering the data. Obviously, the views expressed by the paper do not bind in any circumstance those institutions. We thank the editor, John Eekelaar, and Matilde Machado for helpful comments. We are also grateful to Yeny C. Estrada and Roya $\mathbf{H}$. Samarghandi for editorial assistantship. Nuno Garoupa also acknowledges funding from the Portuguese Government, FCT, PIQS/ $\mathrm{ECO} / 5003 / 2003$. All the remaining errors are our own.

(C) The Author 2009. Published by Oxford University Press. All rights reserved. For Permissions, please email: journals.permissions@oxfordjournals.org. 
Family law is one of the areas of law that increasingly uses specialized courts. Not only are the social implications of family law extremely relevant, but also the contemporary changes in marriage and divorce behaviour have put courts under pressure. More and more people are getting divorced. People are demanding quicker decisions. Growing numbers of children are affected by divorce and their interests are paramount in family law. In civil law countries, the response to the higher rate of divorce, and the consequential impact on an already congested court system, has been the development of a network of specialized family courts. ${ }^{4}$

Based on the existing literature on specialized courts, Table 1 summarizes the advantages and disadvantages of specialized courts in family law. The balance between the advantages and disadvantages of specialized courts is controversial. Legal scholars differ over the weight assigned to these advantages and disadvantages. ${ }^{5}$ In this article, we investigate one of the major arguments in favour of specialized courts in family law, namely, faster decisions in divorce and other familyrelated cases. Clearly, a conclusion that specialized courts reach decisions in a shorter period of time does not necessarily imply that family law is better enforced. However, if specialized courts cannot decide cases faster than regular courts, the argument for specialization endorsed by legal policymakers is certainly less compelling. ${ }^{6}$ Therefore, this is a crucial test.

We use data from a survey of Spanish family courts in the region of Madrid. Spain is a particularly interesting case where specialized family law courts have been actively pursued by legal policy. ${ }^{7}$ Furthermore, recent law reforms have been quite relevant in this matter. First, as a consequence of the new divorce law (Ley 15/2005, of 8 July), there has

Table 1. Costs and benefits of specialized courts

\begin{tabular}{ll}
\hline Advantages & \multicolumn{1}{c}{ Disadvantages } \\
\hline $\begin{array}{l}\text { Higher quality of decisions (in content } \\
\text { and in timing) }\end{array}$ & $\begin{array}{l}\text { Administrative costs of running a new network } \\
\text { of courts } \\
\text { Capture by specialized interests (including a } \\
\text { specialized bar) } \\
\text { Costs of coordination with regular courts } \\
\text { (include losses to incoherence between different } \\
\text { areas of the law and procedure) } \\
\text { Development of vested interests by specialized } \\
\text { judges and court services } \\
\text { Costs of appeal from specialized courts to } \\
\text { non-specialized appeal courts (depending on } \\
\text { the locus of specialization) } \\
\text { Costs of the geographical proximity of courts } \\
\text { to the population (since specialized courts are } \\
\text { usually located in large cities) }\end{array}$ \\
\hline
\end{tabular}


been a significant increase in divorce by mutual consent and a considerable reduction of litigated divorces. ${ }^{8}$ Second, a new legal framework for domestic violence (Ley 1/2004, of 28 December) has effectively transferred important competences concerning divorce and family-related cases to the new specialized courts for domestic and gender violence. Intuitively, it would seem that these changes would have reduced the caseload pressure on family courts (since litigated cases, such as divorce or other family-related cases with issues of custody and alimony, require more time). On the other hand, they have also reduced the benefits of specialization, since fewer complex cases are actually litigated in family courts and therefore the demand for specific knowledge from the court has decreased.

In section 2 , we provide an overview of the family court system in Spain. In section 3, we present the dataset. Section 4 will discuss the regression analysis and section 5 provides the conclusion.

\section{FAMILY COURTS IN SPAIN}

In Spain, there are currently 76 specialized family courts across 25 (of the existing 50) provinces. In 2004, there were 65, confirming the current trend to expand the network of family courts. Generally, family courts are located in the capital city of a province and have permanent teams of psychologists and social workers to assist the judges. Where specialized courts do not have jurisdiction, family law is a matter of regular courts, in particular in the civil courts of first instance in the provinces, where civil and criminal matters are separated. Regular courts share experts on a demand basis. Madrid, alongside Catalonia and Andalucía, are the three regions with the highest volume of family law cases filed. ${ }^{9}$ There can be no forum shopping in family law cases since the cases must be filed in the district of residence of the defendant (the parties cannot choose where to file for divorce).

Our sample includes two specialized courts in the capital city of Madrid (Madrid 24 and Madrid 25) and two regular courts (so-called mixed courts in Spain) from the periphery of Madrid (one from Getafe and the other from Majadahonda). The population of the city of Madrid is only served by specialized courts in family law matters, whereas the population in the periphery is served by regular courts. These four courts have been assessed by the Judicial Council ${ }^{10}$ (the independent body that runs the judiciary) as performing well. ${ }^{11}$ The chosen peripheries serve the capital labour market and are to some extent similar to the capital city in terms of demography ${ }^{12}$ and socioeconomic ${ }^{13}$ variables, thus making the demand for court services as homogenous as possible. ${ }^{14}$ This information is summarized in Table 2. 
Table 2. Some demographics

\begin{tabular}{|c|c|c|c|c|}
\hline & & Madrid & Majadahonda & Getafe \\
\hline GDPpc (2004) & Euros & $16,059.92$ & $22,196.17$ & $12,386.99$ \\
\hline Average age of population (2004) & Years & 41.39 & 34.72 & 38.16 \\
\hline Population density (2004) & Population $/ \mathrm{km}^{2}$ & $5,116.93$ & $1,516.29$ & $1,989.76$ \\
\hline Marriage rate (2004) & Ratio & 4.82 & 4.91 & 4.39 \\
\hline Gender rate $(2004)$ & Ratio F/M & 1.13 & 1.09 & 1.01 \\
\hline $\begin{array}{l}\text { Percentage of population with higher } \\
\text { education (2004) }\end{array}$ & Percentage & 24.37 & 43.77 & 12.58 \\
\hline $\begin{array}{l}\text { Percentage of the population } \\
\text { uneducated (2001) }\end{array}$ & Percentage & 10.32 & 3.61 & 16.18 \\
\hline $\begin{array}{l}\text { Percentage of votes obtained by the } \\
\text { center right (Popular Party) in the } \\
2008 \text { general election }\end{array}$ & Percentage & 50.65 & 62.18 & 39.48 \\
\hline
\end{tabular}

Source: Statistics Institute, Madrid. http://www.madrid.org/iestadis/fijas/estructu/general/terr itorio/im.htm

\section{DATASET}

The data were obtained from these four aforementioned courts for all cases filed from 1 September 2005 to 30 August 2006. We have excluded all filed cases that were still pending by the end of the period, a total of 77 cases (eg, cases filed in the second semester of 2006; this naturally generates an underestimation of the average duration of a case), and all filed cases that were rejected by the courts for procedural reasons (21 cases). These exclusions were determined by purely operational means since the access to the court files is manual (not by computer) and confidential (hence limited in time by the Judicial Council).

We have coded all mutual consent cases, as well as cases subject to litigation. They include divorces but also other family-related matters such as separations (pre-divorce, not mandatory under the new 2005 law), changes in divorce agreements, alimony and custody agreements, and other preliminary or provisional pre-trial issues.

There are 1,549 observations in the dataset, 1,434 cases filed in specialized courts $(100 \%$ of their workload), and 115 cases filed in regular courts $\left(<10 \%\right.$ of their workload).$^{15}$ Also, out of 1,549 cases, $68 \%$ are by mutual consent and $32 \%$ are subject to litigation. However, of the litigated cases, $17 \%$ were in later stages settled by mutual consent; hence, only $15 \%$ of the cases were effectively decided by trial. Divorces represent $84.6 \%$ of the mutual consent ${ }^{16}$ cases but only $43.2 \%$ of cases to be litigated. ${ }^{17}$ Another important difference is that while cases by mutual consent seem to be uniformly distributed over the year, litigated cases peak in September, October, and November. ${ }^{18}$

The duration of a case is the period from the appropriate filing of the case to the moment the judge makes a final decision in either the first 
Table 3. Descriptive statistics

\begin{tabular}{llcc}
\hline Explanatory variables & Mean & Min (no) & Max (yes) \\
\hline Madrid 25 (specialized family court) & 0.494 & 0 & 1 \\
Getafe (regular court) & 0.036 & 0 & 1 \\
Majadahonda (regular court) & 0.047 & 0 & 1 \\
Minors (requires the intervention of family law & 0.692 & 0 & 1 \\
prosecutors) & & & 1 \\
Type of decision taken by the court (final sentence) & 0.805 & 0 & 1 \\
Existence of pre-trial measures & 0.113 & 0 & 1 \\
Need of expert evidence & 0.123 & 0 & 1 \\
Decision to adjourn trial at the request of at least & 0.092 & 0 & 1 \\
one of the parties & & & 1 \\
Administrative procedures that delay trial (eg, & 0.189 & 0 & 1 \\
locating one of the parties) & & & 1 \\
Change to mutual consent procedure & 0.192 & 0 & 1 \\
Legal aid lawyer & 0.194 & 0 & 1 \\
Filed in the second quarter & 0.178 & 0 & 1 \\
Filed in the third quarter & 0.171 & 0 & 1 \\
Filed in the fourth quarter & 0.403 & 0 & 1 \\
Problems with court services (including change of & 0.052 & 0 & 1 \\
judge) & & & 1 \\
Error in filling & 0.282 & 0 & \\
Female plaintiff & 0.539 & 0 & \\
Spanish plaintiff & 0.789 & 0 & \\
Employee & 0.329 & 0 & \\
\hline & & & 1 \\
\hline
\end{tabular}

instance or in a second instance (for those cases that are appealed to a higher non-specialized court).${ }^{19}$ We have excluded the time from the judge's decision to registration in the civil registrar since that is purely administrative and outside of the control of the courts. Cases by mutual consent have an average duration of 87 days and a standard deviation ${ }^{20}$ of 47 days. The corresponding figures for cases subject to litigation are 185 and 91 days, respectively. More detailed information is provided in Table 3.

\section{REGRESSION ANALYSIS}

To analyze the determinants of the duration for the proceedings in family court, we have developed an econometric exercise that allows the identification of the partial impact of the relevant factors on the duration. We determine what variables explain the likelihood that each litigated case will be concluded within a certain period of time. The reason why we concentrate on litigated cases is because they are fundamentally the reason why the specialized family court system developed.$^{21}$ The duration of cases by mutual consent is essentially driven by administrative and other formal procedures and not the need for specific knowledge in managing complex situations. ${ }^{22}$ 
After excluding those cases that were dropped by the plaintiff during the process ( 44 cases in specialized courts and only 1 in regular courts) and those for which we do not have information on at least one of the relevant variables (nine cases), our final sample consisted of 380 observations. For this sub-sample, the average duration in the first instance increased to 190 days and the standard deviation increased to 97 days.

The econometric exercise is based on an ordered probit following Wooldridge (2003). ${ }^{23}$ This technique has been chosen given the characteristics of the dataset, namely, the random variable not being normally distributed or symmetrically distributed. A linear regression model for the average duration, conditional on the explanatory variables, could be inadequate under these circumstances. The ordered probit seems more appropriate. We estimate the ordered probit on the probability of a case subject to litigation being concluded before 125 days, between 126 and 175 days, between 176 and 229 days, and >229 days. This way we can identify which variables have a statistically significant effect on duration and assess their partial impact. Table 4 summarizes the data used in the regression analysis.

We run the regression for the duration of cases in first instance. For robustness, we repeat the exercise for the total duration of the process (the first instance and second instance processes when appealed ${ }^{24}$ ). ${ }^{25}$

We control for the court and the quarter where the process began. ${ }^{26}$ One of the caveats of the study is the small sample size of regular courts, which is only $8.3 \%$ of the sampled cases. Although purely driven by operational constraints as explained before, we believe that this information is enough to get an idea about the differences in duration of cases. As is shown in Table 3, most of the cases start in the fourth quarter of the year ( $40.3 \%$ of the cases) ${ }^{27}$

The variables we use to control for the complexity of the case are the existence of minors (because it requires the intervention of family law prosecutors, $69.2 \%$ of the cases), the existence of pre-trial measures (in $11.3 \%$ of the cases), and the request for expert evidence (in $12.3 \%$ of the cases). Furthermore, we include variables to account

Table 4. Non-mutual consent divorce and other litigious family procedures by duration (dependent variable of ordered probit)

\begin{tabular}{lccccc}
\hline & \multicolumn{2}{c}{ First and second instance } & & \multicolumn{2}{c}{ First instance } \\
\cline { 2 - 2 } Duration & Number of observations & $\%$ & & Number of observations & $\%$ \\
\hline$<125$ days & 81 & 21.32 & 82 & 21.58 \\
Between 125 and 175 days & 87 & 22.89 & 93 & 24.47 \\
Between 176 and 229 days & 89 & 23.42 & 91 & 23.95 \\
$>230$ days & 123 & 32.37 & 114 & 30.00 \\
Total & 380 & 100.00 & 380 & 100.00 \\
\hline
\end{tabular}


for administrative procedures that can affect the duration of the case. The variables accounted for, which delay trial in administrative procedures, are

- locating one of the parties,

- making a request for a legal aid lawyer, and

- problems with court services (including change of judge).

Finally, error in filing is also included. That is a good proxy for the quality of legal services offered by the lawyers.$^{28}$ We have not included the decision to change the procedure from litigation to mutual consent (19.2\% of the sample), since most of them occurred in one particular court (Getafe), where apparently the judge actively favoured this kind of solution. We also have collected information about individual characteristics of the plaintiff and the defendant such as gender, nationality, and labour status. ${ }^{29}$

We present the main econometric results in Tables 5 and $6 .^{30}$ The baseline case ${ }^{31}$, to which the econometric results must be compared, is one with the following characteristics:

- filed in the first quarter in the specialized family court Madrid 24,

- being concluded with preliminary measures or dropped (hence not reaching a final decision),

- does not require the intervention of the family law prosecutors (hence no minors were involved),

- exhibits low complexity (no pre-trial measures or expert evidence was requested),

- no party requested an adjourning trial,

- no administrative proceedings delayed trial, and

- no request for legal aid lawyer were made, no problems with court services, and there were no errors in the filing.

With probit models, the estimated coefficients cannot usually be directly interpreted. The relevant information is their sign, which permits a qualitative evaluation. The sign of a given coefficient shows the impact of the independent variable on the likelihood that the duration is one of the four categories. In order to facilitate a correct interpretation, the estimated coefficients refer to the marginal effect of each category.

Generally, the estimated coefficients of the variables used as the controlled variables have the expected signs. Tables 5 and 6 show (for first instance only and for total duration, respectively) that Madrid 24 is faster than all the others, although other important variables have 
NUNO Garoupa NATALIA JORGENSEN, AND PABLO VAZQUEZ 61

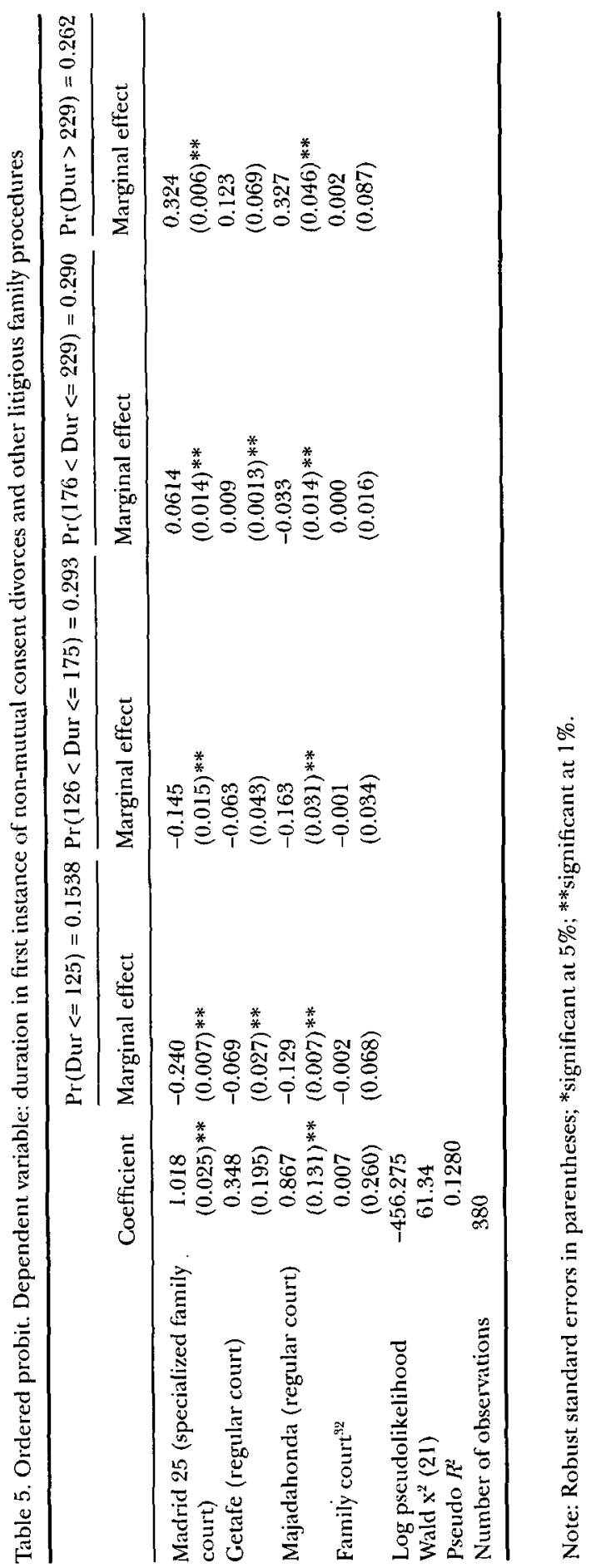




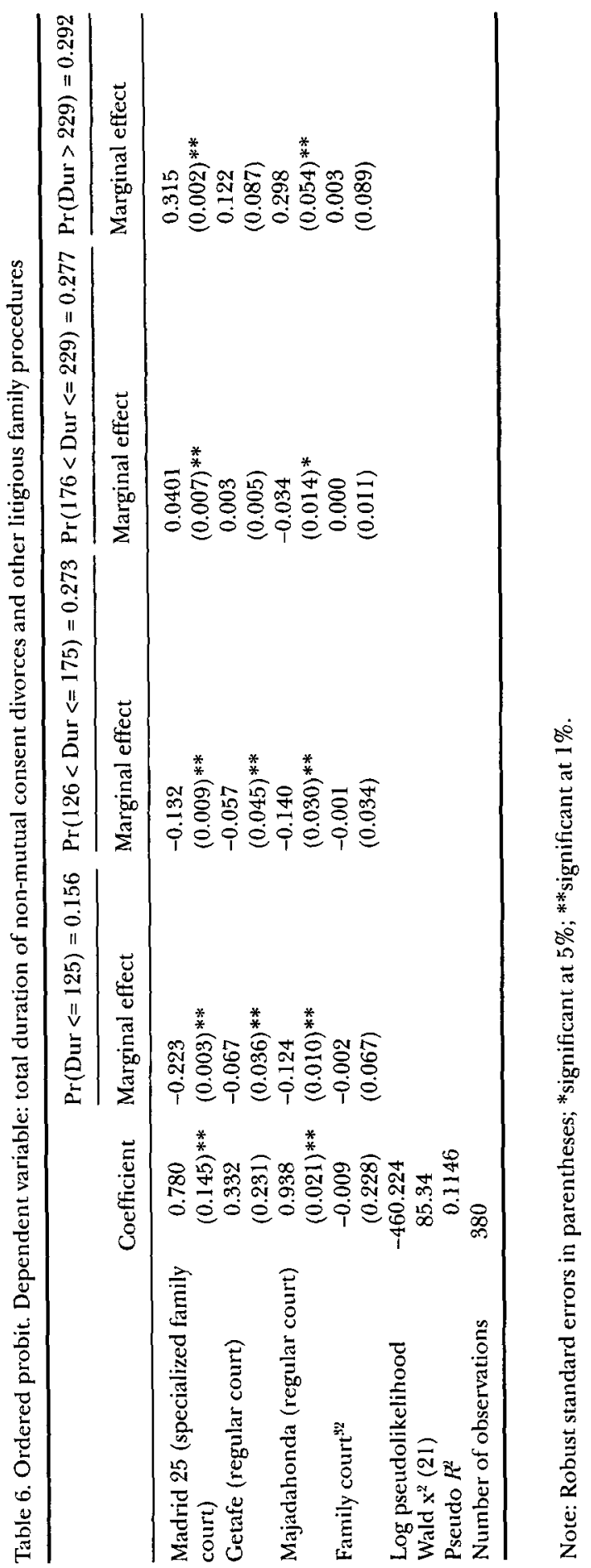


significant explanatory power. Apart from the court where the proceedings take place, the statistically significant variables with a positive marginal impact are the type of decision taken by the court (final order or preliminary measures subject to later review), whether there is a decision to adjourn at the request of one party, the existence of administrative procedures that delay trial, and presence of errors in filing for divorce or other family-related procedures that need to be corrected before the proceedings start.

A negative sign means that the explanatory variable has a negative impact on the duration of a proceeding in a family law case. For example, the existence of minors also generates interesting results when it is an issue in the different courts (with the interpretation that judges are concerned with resolving the cases quickly to serve the minors' interests). Pre-trial measures as expected have a negative sign but are not statistically significant; the need of expert evidence, representation by legal aid lawyer, and problems with court services as expected have a positive sign but again do not have a statistically significant impact.

The econometric model also provides for the probabilities of each category of duration conditional on the explanatory variables. These probabilities are 0.154 (<125 days), 0.293 (from 126 to 175 days), 0.290 (from 176 to 229 days), and 0.262 ( $>229$ days) for the total duration and 0.156 ( $<125$ days), 0.273 (from 126 to 175 days), 0.277 (from 176 to 229 days), and 0.292 (>229 days) for duration in first instance only.

The estimations are fairly robust to the different specifications. We have also developed a further test of robustness by running identical regressions with a dummy for family courts (Madrid 24 and Madrid 25) and regular courts (Getafe and Majadahonda). As expected, the coefficient for family courts is not statistically significant, as seen at the bottom of Tables 5 and 6 .

\section{CONCLUSIONS}

By looking at some family courts in Spain, we have assessed the extent to which specialized courts are actually faster in reaching a decision. This is an important test for any that is based on the higher quality of specialized courts. The econometric evidence is not strong but seems to point out that specialized courts (in our sample, particularly Madrid 24) could conclude litigation with a lower average duration than regular courts (in our sample, Getafe and Majadahonda), after controlling for other important variables. However, the overall results do not provide strong support for the claim that specialized courts, when handling family cases, are indeed faster. 
Obviously, these empirical results are not to be hastily generalized since we do not have an exhaustive set of information about each case that allows us to explore other potential relevant variables. Furthermore, one should not confuse assessing the duration with a fully fledged evaluation of the merits of court specialization in family law. Nevertheless, the results are sufficiently important to contrast with the conventional optimism of legal policymakers for court specialization. The results suggest caution and ask for a more comprehensive assessment. They also point out that current optimism should be carefully restrained.

\section{NOTES}

'See Guarnieri (2001).

${ }^{2}$ See Dreyfuss (1990) at pp. 393-96.

${ }^{\mathrm{s}}$ See, among others, Posner (1983), Revesz (1989), Dreyfuss (1989), and Bagley and Revesz (2006).

${ }^{4}$ Similarly in USA and in Australia. See, eg, Babb (1998), Nicholson and Harrison (2000), and Kelly and Fehlberg (2002).

${ }^{5}$ See, among others, supra 3.

${ }^{6}$ There is a potential trade-off between speed and quality of decisions. The balance between the advantages and disadvantages should address this question. Broadly speaking, speed has been presented as a major goal of court reform in Spain. For example, the new 2005 divorce law has explicitly favoured speedier solutions to divorce and has abolished the need for prior separation and waiting or cool-off periods.

${ }^{7}$ For a general overview, see Merino Blanco (2006) at 69.

${ }^{8}$ Family law in Spain has been reformed since the end of the Franco dictatorship in 1975 (see, among others, de Ussel, 1991). A new law concerning marriage was passed in 1981 (Ley 30/1981, of 7 July) to separate marriage law from canon law, hence recognizing marriage as a legal institution of civil law. It also regulated divorce. A recent law (Ley 13/2005, of 2 July) has extended marriage to homosexual couples.

${ }^{9}$ Madrid has 11 family courts (2007) of which we study two.

${ }^{10}$ Consejo General del Poder Judicial.

${ }^{11}$ Information provided orally to the authors.

${ }^{12}$ Marriage and gender (female to male) rates are very similar.

${ }^{13}$ Majadahonda's population is more white-collar professionals (lawyers, medical doctors, and university professors) who work in Madrid, whereas Getafe is more blue-collar working class who also work in Madrid. The economic and electoral statistics reflect these different population compositions. See the information available in Table 2.

${ }^{14}$ Ideally we would like to control for all possible variables to avoid any kind of identification problem. Unfortunately, given the available information, that is not possible, and this was the best approach to design the sample.

${ }^{15}$ The significant difference in terms of workload is justified by the geographical location of the courts and the resident population density (see Table 2 for more information). As we have noted before, there is no forum shopping.

${ }^{16}$ There are 895 divorces, 88 pre-divorce separations, 49 alimony and custodial agreements, and 26 changes of mutually agreed family-related issues.

${ }^{17}$ There are 212 divorces, 105 pre-trial measures, 73 not mutually agreed family-related issues, 49 alimony and custodial decisions, 23 pre-divorce separations, and other 29 family law disputes.

${ }^{18}$ In the popular press, this excessive filing in the fourth quarter has been described as a consequence of the post-Summer vacations' trauma.

${ }^{19}$ The second instance consists of ordinary courts (not specialized in family law) with jurisdiction over civil and criminal matters located in each capital of province (Audiencias provinciales). 
${ }^{20}$ The standard deviation is a measure of the dispersion of the sample around the average. A low standard deviation indicates that the individual duration of each case is close to the average; a high standard of deviation indicates that the individual duration of each case is spread out over a range of possible values.

${ }^{21}$ In fact, there is also a pragmatic reason. The court files are not so informative for mutual consent cases. Even for litigated cases, we had to exclude nine cases due to lack of information concerning at least one of the explanatory variables.

${ }^{22}$ Delay and costs can be determined by different variables. In Britain, eg, there are constructive and structural reasons for delay but also other significant factors such as legal aid, obstructiveness of the parties, and solicitor-induced delays. Parties might be advised by lawyers with a direct income interest on propelling people to divorce. The evidence, however, does not seem to support strongly such claims (Eekelaar et al, 2000), at chapter 8.

${ }^{23}$ See Wooldridge (2003). A probit model is an econometric specification for a dependent variable that follows a binary distribution function (eg, zero if no and one if yes). An ordered probit is a generalization of the probit model for ordinal dependent variables that follow a multinomial distribution. The dependent variable is ranked from a list of possible values; in our case, the probability of a case subject to litigation being concluded within a time span.

${ }^{24}$ The number of appealed sentences is 12 ( 11 in specialized courts and 1 in regular courts), all confirmed in the second instance.

${ }^{25}$ We use STATA 10 for the regression analysis.

${ }^{26}$ Denoting the beginning of the case the date, the plaintiff brings the lawsuit in the form that the court considers to be procedurally correct.

${ }^{27}$ See supra 18.

${ }^{28}$ We also have information about the quantity of lawyers for each party as well as whether they changed lawyers during the proceedings. However, they are very small numbers and, therefore, have not been included in the regression analysis.

${ }^{29}$ We include these variables in two of the specifications to evaluate the robustness of our results in the working paper version, Garoupa et al (2009).

${ }^{30}$ Extended results are available at Garoupa et al (2009)

${ }^{91}$ By baseline case in a probit regression, we describe the econometric model when each dummy variable takes a zero value. The sign of each coefficient of the regression provides a statistical measure of the effect (positive or negative) of that variable on the dependent variable.

${ }^{32}$ Dummy variable for both Madrid 24 and Madrid 25 family courts.

\section{REFERENCES}

Babb, B. A. (1998) 'Where we stand: an analysis of America's family law adjudicatory systems and the mandate to establish unified family courts', Family Law Quarterly 32, 31.

Bagley, N. and Revesz, R. L. (2006) 'Centralized oversight of the regulatory state', Columbia Law Review 106, 1260.

de Ussel, J. I. (1991) 'Family ideology and political transition in Spain', International Joumal of Law, Policy and Family 5, 277.

Dreyfuss, R. C. (1989) 'The federal circuit: a case study in specialized courts', New York University Law Review 64, 1.

Dreyfuss, R. C. (1990) 'Specialized adjudication', BYU Law Review, 377.

Eekelaar, J., McLean, M. and Beinart, S. (2000) Family Lauyers: The Divorce Work of Solicilors, Oxford: Hart Publishing.

Garoupa, N., Jorgensen, N. and Vazquez, P. (2009) Assessing the Argument for Specialized Courts: Evidence from Family Courts in Spain. SSRN Working-Paper. Available at http://papers.srn.com/ so13/papers.cfm?abstract_id=1446875.

Guarnieri, C. (2001) Judicial independence in Latin countries in Western Europe in P. H. Russell and D. M. O'Brien (eds), Judicial Independence in the Age of Democracy, Critical Perspectives Around the World, Charlottesville, VA: University of Virginia Press.

Kelly, F. and Fehlberg, B. (2002) 'Australia's fragmented family law system: jurisdictional overlap in the area of child protection', International Journal of Law, Polig' and Family 16, 38.

Merino Blanco, E. (2006) Spanish Law and Legal System, 2nd edn, London: Sweet \& Maxwell.

Nicholson, A. and Harrison, M. (2000) 'Family law and the family law of Australia: experience of the first 25 years', Melbourne University Law Review $24,756$. 
Posner, R. (1983) 'Will the federal courts of appeals survive until 1984? An essay on delegation and specialization of the judicial function', Southern California Law Review 56, 761.

Revesz, R. L. (1989) 'Specialized courts and the administrative lawmaking system', University of Pennsylvania Law Review 38, 111.

Wooldridge, J. (2003) Econometric Analysis of Cross-Section and Panel Data, Cambridge, MA; London, England: MIT Press. 